\title{
The three facets of the adaptation of expatriates to Morocco under the effect of the family profile
}

\author{
Lamiaa Laouami, Mohammed Faridi
}

University Hassan I, ENCG, Settat, Morroco

\begin{abstract}
The geographical position, political stability and market opportunities offered by Morocco have attracted the interest of several multinational companies either through acquiring local companies or setting up new subsidiaries. As a way of securing adequate competencies in new markets, these companies resort to the expatriation of their executives. However, this strategy does not come without direct consequences or hidden costs.

In this context, researchers and managers are urged to explore the reasons for the expatriation of executives.

Hence, the aim of this research is to test the model of Roger and Mérignac (2005), while focusing on the family profile and the impact of the family on the adaptation of the expatriate in Morocco.

Within this research, a number of hypotheses were formulated and to verify them we will adopt a quantitative approach.

The results revealed a slight difference in the adaptation according to the family profile. The most suitable expatriates are those who are accompanied by their families. Nevertheless, these results confirm the general tendency of the researchers on this problematic. A study with a larger sample would show better results.
\end{abstract}

Keywords - expatriation, expatriate, adaptation, family profile.

\section{INTRODUCTION}

Morocco has many advantages to attract foreign investors to its territory. Its geographical position as well as political stability makes it a stable market where foreign companies invest at lower risk, especially as the business climate is constantly improving due to the voluntary reforms undertaken by the kingdom.

The market opportunities as well as the many advantages offered by Morocco attracted the interest of the multinational companies. These companies opt either for the acquisition of national companies or for the establishment of new subsidiaries.

To facilitate the establishment of subsidiaries, these companies resort to what is called expatriation of executives.

Research has shown that the average cost for a multinational company to expatriate an executive is $\$$
300,000 per year (O'Boyle, 1989). Black and Gregersen (1991) and Black and Stephens (1991) state that between $16 \%$ and $40 \%$ of international assignments often fail. This has prompted researchers and business leaders to explore the real reasons for expatriation failures.

Black (1988) associates the failure of expatriation with inefficiency and poor performance, while Fuduka and Chu (1994) associate it with the return to the country before the end of the mandate. For Cavusgil, Yvas and Bykowicz (1992), failures result from expatriate inefficiency, resulting in stagnation of activities, loss of market share, or degradation of the company's reputation. In these cases it is essential to identify the causes of these failures and to determine the factors that may foster for a better expatriation.

In the literature, the causes of failure are essentially family, cultural and linguistic difficulties or are linked to the conditions offered by the company.

Among family difficulties, Harris (1993) addresses the problem of dual careers. For Roger and Mérignac (2005); And Waxin and Chandon (2003), the role of the family is an inevitable aspect for the adaption of the expatriates.

This impotence of the family directly impacts the adaptation of the expatriate (Black and Gregersen 1991, Fuduka and Chu 1994, Waxin and Chandon 2003, Mérignac and Roger 2005).

Oter authors (Arthur and Bennett, 1995; Richardson, 2006) found that adapting the expatriate's spouse and family is a major factor explaining the success of international assignments.

Adaptation is defined in the literature as "the degree of psychological comfort of a person with several aspects of a new environment". Black (1988), in his study, explains three aspects of adaptation: adapting to responsibilities of work ,performance expectations and supervisory responsibilities; adapting to the interaction between the national of the Host country and expatriate in terms of socialization and communication with nationals, and general adjustment regarding the living conditions in the host country. This typology has been approved by several authors.

These studies propose better approaches to the problems posed by expatriation and adaptation of the expatriate. 
However, they do not give us any details on the adaptation of expatriates in Morocco.

Hence, the objective of this research is to test the model of Roger and Mérignac (2005), while focusing on the family profile and the impact of the family on the adaptation of the expatriate in Morocco. So, the impact of the family acts as a direct influence which in turn constitutes a decisive factor in the adaptation of the expatriate.

Our research aims to answer the following questions: What is the relative importance of the history of adaptation? What is the direct effect of the family profile on adaptation? What is the moderating effect of the family profile on the antecedents of adaptation?

In the first part we will present a literature review and a model of analysis that will serve as a basis for the formulation of our hypotheses. In the second part, we will expose the methodology of our research. In the third part, we give the results of our research. Finally, we will discuss these results and present their limits and their managerial implications.

\section{THE LITTERATURE REVIEW}

Our research is based on Roger and Merignac model (2005) which highlights three categories of explanatory variables for adaptation: organizational variables, individual variables, and contextual variables. (Diagram1).

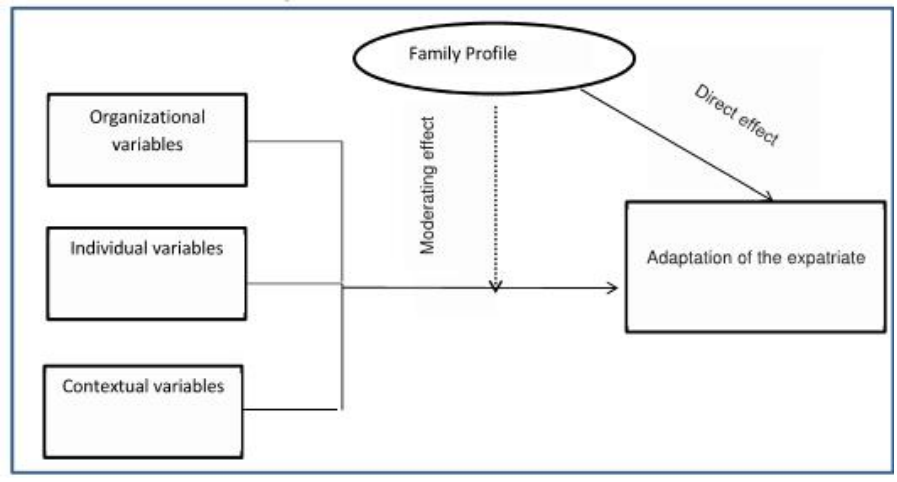

Diagram 1: Research model (From the analysis model of Olivier Mérignac (2005)

\subsection{Organizational variables}

Organizational variables include variables related to work, organizational social support and intercultural preparation.

\subsubsection{Clarity of the job}

The clarity of the role is the ability of the expatriate to perform his/her new duties without too much reliance on his/her colleagues or supervisor, and thus the clarity of the role facilitates the adaptation of the expatriate as he /she becomes more familiar with the requirements of His /her new position.
Black and Gregerson (1991), Aryee and Stone (1996), Cerdin (1999), consider a positive relationship between clarity of role and adaptation to work.

\subsubsection{Autonomy in the job}

Autonomy in the job represents the individual's freedom of action in carrying out his/her responsibilities or freedom of authority and decision in his/her works (Aryee and Stone, 1996). Nicholson (1984) and Brett (1980) argue that greater autonomy in the job and the work environment is more important to the adaptation of the expatriate to the situation.

\subsubsection{Organizational dissimilarity}

This variable deals with the aspect of the difference between the organizational practices implemented in the host country and those of the parent company.

Some authors such as Mendenhall and Oddou (1985) find that the novelty of organizational culture increases uncertainty due to changes in the working environment.

Indeed, s substantial difference in the practices of managing the new work environment with those of the former position of the expatriate may create obstacles in the adaptation of the expatriate.

\subsubsection{Support from colleagues}

The support of colleagues is the help provided by colleagues of new job of the expatriate. So the ease of the interactions with colleagues will offer a sense of comfort and security to the expatriate, who will help him / her to adapt better in his or her workplace.

\subsubsection{Organizational support}

According to Walter and Marks (1981), "a physical, emotional or symbolic contribution to individuals increases their net capacity to cope with change". The support of the superior is essential to encourage the expatriate in the accomplishment of his/her tasks. Cerdin (1999) indicates that the support of the parent company is a major element in the adaptation of the expatriate.

\subsubsection{Intercultural training}

Intercultural training is the process of preparing the expatriate and his / her family for the challenges of their new environment.

According to Waxin, Roger, Chandon (1997), in the majority of multinational companies, the intercultural preparation of the expatriates is insufficient or even not existing.

For Waxin and Panaccio (2004), intercultural training has a positive effect on the three aspects of adaptation. This effect is more pronounced among expatriates with less international experience.

\subsection{The individual variables}

The individual variables are the five aspects of adaptability listed by Mérignac and Roger (2005) in addition to international experience and knowledge of the language of the host country. 


\subsubsection{The adaptability of the individual}

Cerdin (1999), based on the work of Mendehall and Oddou (1985) and an empirical study on the determinants of adaptation of French expatriates, highlights six components of adaptability: , Ability to substitute, willingness to communicate, social orientation, confidence in one's skills and ability to withdraw.

\subsubsection{The knowledge of the language of the host country}

This variable assesses the individual's ability to interact with nationals of the host country.

\subsubsection{Previous international experience}

Black (1988) shows that previous experiences in terms of expatriation only alleviates the difficulties of adaptation to the new position. On the other hand, Parker and McEvoy (1993) and Cerdin (1999) estimate that international experience is significantly correlated with only the general adaptation.

\subsection{Contextual variables}

Contextual variables include time spent in the host country, cultural differences, standards of living, and support from associations.

\subsubsection{Time spent in the host country.}

The individual needs time to adapt with his/her new environment. Cerdin (1999) considers that time has a positive effect on the adaptation to work and on the general adaptation of French expatriates. While Janssens (1995) finds that there is no relationship between time spent in the host country and adaptation to work for Belgian and British expatriates.

\subsubsection{Quality of life}

This variable concerns the financial capacity of the expatriate and his / her family to buy good services, depending on the income available to them. The standard of living is one of the variables that determine the general adaptation of the spouse.

\subsubsection{Perceived Cultural Difference}

The perceived cultural difference corresponds to the difference between the values acquired and transmitted in the society of the host country and those of the country of origin of the expatriate.

\subsubsection{Support for associations}

The expatriates often coalesce in association to help their compatriots to facilitate the general adaptation, in particular, the main needs.

\section{HYPOTHESES}

The study we are conducting focuses on the adaptation of expatriates in Morocco. The objective of this research is to test the model of Roger and Mérignac (2005), while focusing on the family profile and the impact of the family on adaptation of the expatriate framework in Morocco. So the impact of the family acts as a direct influence, and thus constitutes a decisive element of the adaptation of the expatriate. Thus, the hypotheses formulated below, try to test the model of Roger and Mérignac (2005) in the Moroccan context, while evaluating the impact of the family.

H1: Expatriates accompanied by their families easily adapt to their new environment than single expatriates.

H2: The difficulties of the spouse to adapt negatively affect the adaptation to the interaction of the accompanied expatriate.

H3: The general adjustment of the expatriate is positively affected by the support of the spouse.

H4: The support of colleagues at work has a positive effect on the expatriate's adaptation to work.

H5: Autonomy in the job positively influences the adaptation of expatriates to work whatever the family profile.

H6: Adaptation to expatriate interaction is positively related to confidence in one's skills, regardless of one's family situation.

H7: The adaptation to the work of the expatriate is positively linked to the confidence in his / her skills regardless of his / her family situation.

\section{METHODOLOGY AND DATA COLLECTION}

We intent in this research to underway a causal quantitative study by questionnaire. We have adopted a hypothetical-deductive approach. Our sampling strategy is based upon two criterions: expatriates should be working in Morocco and their mandate of the expatriate should be more than six months.

The sample is composed of 50 expatriates who have been working for at least six months in Morocco. Thus, there are 30 men and women who contributed to the study. The average age is 38 years. The majority of the respondents come from countries in Western Europe. These expatriates operate in various fields teaching, building and public works, architecture, finance, etc.

The sample is composed of 20 singles that represent $40 \%$ of the sample. 18 Claim to have children and to be accompanied by their family. 4 Are couples without children and accompanied by spouse. 3 Claim to have children but not be accompanied by family and one expatriate claim to have come without a spouse.

The data were collected by means of a questionnaire administered to expatriate executives in Morocco.

The answers collected through this questionnaire were analysed using SPSS. Our data analysis is based on variance analysis and multiple regression analysis. 


\section{THE MEASUREMENT OF VARIABLES}

The questionnaire was divided into several parts referring to the adaptation of expatriate executives and the influence of the spouse.

To measure the adaptation to expatriation we take the scale of Black and Stephens (1989). The three facets identified by these authors are confirmed by an analysis of the reliability of the statements measuring adaptation. For independent organizational variables, the clarity of the position is adjusted to the scale of Breaugh and Colihan (1994) taking into account the context in which the study was carried out. The measure of autonomy is taken from the scale of Black and Gregersen (1991), that of organizational support adapted to the scales of House and Wells (1978) and of Cerdin (1996), who breaks it down into logistic support and social support by the superior, by the colleagues or by the organization, that of the organizational dissimilarity for which we adopt the scale of Cerdin (1996); and finally managers who indicate whether they have received intercultural or linguistic training.

For explanatory variables that include individual characteristics, adaptability is measured by an adapted scale of Cerdin (1996) with five dimensions: openness, confidence in one's skills, communication capacity, substitution, and social orientation. International experience refers to the cumulative duration of foreign experiences and levels in the language of the host country and which are measured on a scale of five modalities.

The environmental variables are measured on a threelevel scale, for cultural difference we adapt the scale of Black and Gregersen (1991).

\section{RESULTS}

\section{Moderating effect of expatriate adjustment} variables

By testing the effect on family profit on the three facets of the adaptation we carried out an analysis of variance to see to what extent the family profile explained the adaptation of the expatriates. In Table 1, we note that the overall effect of the family profile on the adaptation of expatriates is important because one finds $15 \%$ the general adaptation, $29 \%$ adaptation to the interaction, and $38 \%$ Adaptation to work.

Table 1: Analysis of the direct effect of the family profile

\begin{tabular}{|c|c|c|}
\hline & Eia & Elis Squarand \\
\hline $\begin{array}{l}\text { Geveral adaptation" Fumily profile } \\
\text { adaptation to the interaction" Family profile } \\
\text { Adaptation to wurk" Fumily profile }\end{array}$ & $\begin{array}{l}.150 \\
.292 \\
.382\end{array}$ & $\begin{array}{l}.023 \\
.085 \\
.146\end{array}$ \\
\hline
\end{tabular}

The analysis of this study showed that despite a significant direct effect of the different family profiles on the adjustment, the differences between each family situation are not important.

In general, all expatriates responded well to their work environment. The majority of expatriates mention that they are well adapted to the statements about work adaptation and adaptation to interaction. Only the general adjustment was not too easy for all expatriates.

\section{Moderating effect of expatriate adjustment} variables.

\subsection{For singles}

Autonomy in the position, organizational support and logistical support are organizational variables with more moderating effects on work adaptation and adaptation to the interaction of single expatriates.

Autonomy in the position is a more moderating variable than the other variables on the adaptation of single expatriates

Openness and cultural difference are individual variables that play an important role for bachelors in adapting to interaction.

\subsection{For accompanied expatriates}

Unlike single expatriates, clarity of the job, support of colleagues, support of the superior and organizational dissimilarity are the organizational variables that allow a better adaptation to the work of the accompanied expatriates.

In terms of individual variables, confidence in one's skills, perceived cultural difference, and willingness to communicate better explain the adaptation to work for accompanied expatriates.

\subsection{Impact of spouse}

The results of this study revealed that the spouse plays a role in the adaptation of the expatriate but not in the foreground. Thus, the adjustment of the majority of expatriates is explained by parameters other than the family profile and the support of the spouse.

\section{DISCUSSIONS}

In this part we will discuss the impact of certain individual, contextual and organisational attributes on the degree of adaptation of the expatriates, as well the moderating effect of the marital status.

The direct effect of our model is the impact of marital status of the expatriate at the time of his/her international assignment on his/her adaptation. Indeed the literature revealed that certain authors such as Cerdin (1996) had similar results showing that the marital status has a significant impact on the adaptation. Furthermore, Mérignac (2005) considers that each family profile develops a specific process of adjustment. 
Whereas other authors such as Waxin (2000) did not find any significant impact of the marital status of the expatriates on the adaptation.

For our study, the analysis carried out revealed that despite the significant effect of different marital statuses on the adaptation, the differences between each one are not important.

Some studies (Waxin andChardon, 2000; Roger and Mérignac, 2005) showed that the selected variables have a moderating effect on the adaptation of the expatriated executives. With regards to our study, certain organisational and individual attributes facilitate the adaptation of the expatriates, dependently of their marital status.

For the single expatriates, the individual attributes influence their adaptation to work and to the interaction to facilitate their integration.

In reference to the review of literature, certain authors (Roger and Mérignac, 2005; Waxin and Chardon, 2003, and Shoffer et al., 1999) revealed that the role of the spouses acts as a direct influence on the degree of the adaptation of the expatriate. In our study, the adaptation of the majority of expatriates is explained by other parameters than the marital status.

\section{CONCLUSION}

\section{Research contribution}

This research analyses the impact of the family profile on the adaptation of expatriates and their background.

Regarding the effect of the family profile on the three aspect of adaptation, Mérignac (2005) specifies that each family profile deploys a specific adaptation process, thus expatriates who are not accompanied by their family have a lower level of adaptation compared to expatriates accompanied or single, and this on the three aspects of adaptation.

In the analysis of our results, expatriates as a whole have adapted well. Despite the small size of our sample, unaccompanied expatriates claimed that they filled their spouse's absence with an emphasis on work at the expense of adaptation to interaction.

As for the moderating effect of the expatriate adjustment variables, the studies by Waxin and Chandon (2000) and Roger and Mérignac (2005) have shown that the selected variables may have moderating effects on the adaptation of expatriates. At the level of our study we found that some organizational and individual variables have the effect of facilitating the adaptation of the expatriates while taking into account their family profile.

For the study of the impact of the spouse on the adjustment of expatriates, we referred to Roger and Mérignac (2005) who presented the role of the spouse in the international assignment. So the spouse directly influences the three aspects of the expatriate's adjustment. According to our results, the role of the spouse is important but not decisive; this is explained by the fact that expatriates in Morocco do not live enormous difficulties of adaptation so that they resort to their family.

Some research (Cerdin in 1996, Waxin and Chandon in 2003, Lee in 2005, Roger and Mérignac in 2005) have studied the impact of the family on the adaptation of expatriates, but these studies have been carried out in general, in the Middle East, some countries of Eastern Europe, and in Asian countries. So, our contribution is to give an overview of the adaptation of the expatriates in Morocco while putting emphasis on the family profile.

Finally, our study reveals that the optimal management of expatriates must take into account the family profile, it is very important for multinational companies to expatriate employees with their families for a better professional, social and emotional balance and therefore a better productivity

\section{Search Limits}

For this study, we used rigorous data collection and analysis methods to promote the validity of the results. In fact, two limits will be presented in the following paragraphs.

The first limit concerns the size of the sample; a study with a larger sample would give better results. Indeed, the reduced number of respondents from the unaccompanied expatriate sub-sample did not allow multiple regressions analyses to estimate the impact of organizational, contextual and individual variables on this family profile. It is likely that better outcomes will be achieved by increasing the number of unaccompanied expatriates.

The second limitation concerns the measurement of spousal adjustment, and we found that more statements needed to be developed to better measure this adaptation because we were puzzled by the results.

\section{REFERENCES}

[1] Black, j. sewart. 1988. «work role transitions: a study of american expatriete managers in japan ». journal of international busniss stuedies.vol.19,277294.

[2] Black, j. stewart, and h. b gregerson. 1991. «antecedents to cross-culturel adjustement for expatrietes in pacific rim assifnements ». human relations. vol 44. no 5.p.497-515.

[3] Black, j. stewart, mark mendenhall and gary oddou. 1991. «toward a comprehensive model of international adjustment: an integration of multiple theoretical perspectives». academy of management review. vol.16, no 2. 
[4] Black, j. stewart, et g. k stephens. 1989. «the influence of the spouse on american expatriate adjustment in overseas assignments». journal ofmanagement. vol. 15, p. 529-544.

[5] caligiuri, rm. 2000. «the big five characteristics as predictors of expatriates' desire to terminate the assignment and supervisor-rated performance». personnel psychology. vol. 53, p. 66-88.

[6] cavusgi 1, tamer, ugur yavas et sandy bykowicz. 1992. «preparing executives for overseas assignments». management decision. vol. 30, no 1 , p. 54.

[7] cerdin, j. 1. 1999. « la mobilite internationale: reussir l'expatriation ». paris: éditions d'organisation.

[8] cretien, helene. 2003. «la notion d'adaptation pour des expatries d'une grande entreprise internationale allemande dans des pays en transition». management international. vol. 7, no 3, p. 39.

[9] Forster, nick 2000. «expatriates and the impact of cross-cultural training». human resource management journal. vol. 10, no 3, p. 63 .

[10] Fuduka, k. j, et p chu. 1994. «wrestling with expatriate family problems. japanese experiences in east asia». international studies of management and organisations. vol. 24, p. 36-47.

[11] Halden, anders, et towers perrin. 2007. «the mobile family». benefits \& compensation international. vol. 36 , no 6, p. 40 .

[12] Harris, james e. 1989 . «moving managers internationally: the care and feeding of expatriates». hr. human resource planning. vol. 12, no l, p. 49.

[13] Harris, james e. 1989. «moving managers internationally: the care and feeding of expatriates». hr. human resouree planning. vol. 12, no l, p. 49.

[14] Harvey, m. g. 1985. «the executive family: an overlooked variable in international assignments». columbia journal ofworld business. vol. 20, p. 84-92.

[15] Harvey, m. g. 1996. «adressing the dual-career expatriation dilemma». human resource planning. vol. 19 , no 4 .

[16] Haslberger, arno 2005. «facets and dimensions of cross-cultural adaptation: refining the tools». personnel review. vol. 34, no 1, p. 85-109.

[17] Holopainen, jonna, et ingmar bjorkman. 2005. «the personal characteristics of the successful expatriate: a critical review ofthe literature and an empirical investigation». personnel review. vol. 34 , no 1, p. 37.

[18] Julia, richardson. 2006. «self-directed expatriation: family matters». personnel review. vol. 35 , no 4 , p. 469.

[19] Lee, h. w 2005. «the factors influencing expatriates». journal ofamerican academy of business, cambridge. vol. 6, no 2, p. 273.
[20] Marie-france, waxin, et panaccio alexandra. 2005. «cross-cultural training to facilitate expatriate adjustment: it works!». personnel review. vol. 34, no 1, p. 51.

[21] Mendenhall, mark, e. , edward dunbar et gary oddou, r.. 1987. «expatriate selection, training and career-pathing: a review and critique». human resource management (1986-1998). vol. 26, no 3, p. 331

[22] Mendenhall, m., et g oddou. 1985. «the dimensions of expatriate acculturation: a review». academy ofmanagement review. vol. 10, p. 39-48.

[23] Merignac, olivier, et alain roger. 2005. «l'impact du conjoint et de la famille sur l'adaptation des cadres expatries ». revue de gestion des ressources humaines. vol. 58

[24] Nicholson, n. 1984. «a theory ofwork role transitions». administrative science quarterly. vol. 29, p. 172-191.

[25] Nick, forster. 2000. «expatriates and the impact of cross-cultural training». human resource management journal. vol. 10, no 3, p. 63.

[26] O'boyle, thomas, f 1989. «grappling with the expatriate issue --- little benefit to careers seen in foreign stints». wall street journal, p. 1.

[27] Ouellet, fernando and baillargeon, gérald. 2005. analyse de données avec spss pour windows: smg, $205 \mathrm{p}$.

[28]Parker, b, et g. m mcevoy. 1993. «initial examination of a model of intercultural adjustment».1nternational journal ofintercultural relations. vol. 17, p. 336-353.

[29]Peppas, c. spero 2004. «making the most of international assignments: a training model for nonresident expatriates». journal of american academy ofbusiness, cambridge. vol. 5 , no 1/2, p. 41.

[30] Pierre, philippe 2001. «les cadres internationaux, construction identitaire et mobilisation de l'ethnicite>>. sociologies pratiques. vol. 4.

[31] Richardson, julia 2006. «self-directed expatriation: family matters». personnel review. vol. 35 , no 4, p. 469.

[32] Selmer, Jan. 2000. «usage of corporate career development activities by expatriate managers and the extent oftheir international adjustment». international journal ofcommerce \& management. vol. 10 , no 1 , p. 1 .

[33] Selmer, jan, et hon lam. 2004. ««third-culture kids» future business expatriates? ». personnel review. vol. 33 , no 4, p. 430-445.

[34] Shaffer, Margaret a, david a harrison et matthew $\mathrm{k}$ gilley. 1999. «dimensions, determinants, and differences in the expatriate adjustment process». 
journal of international business studies. vol. 30, no 3.

[35] Shay, jeffrey, p, et a baacksally. 2004. «expatriate assignment, adjustment and effectiveness: an empirical examination of the big picture». journal ofinternational business studies. vol. 35, no 3, p. 216.

[36] shupe, e. 1, et le mcgrath. 1998. «stress and the sojourner». p. 86-100: In cooper editions.

[37] Spero, c. peppas. 2004. «making the most of international assignments: a training model for nonresident expatriates». journal ofamerican academy ofbusiness, cambridge. vol. 5, no 1/2, p. 41.

[38] Stafford, jean and paul, bodson. 2006. l'analyse multivariee avec spss. sainte-foy (quebec): presses de l'universite du quebec, $245 \mathrm{p}$.

[39] Takeuchi, riki, mo wang et sophia marinova, v 2005. «antecedents and consequences of psychological workplace strain during expatriation: a cross sectionnai and longitidunal investigation». personnel psychology. vol. 58, no 4, p. 925.

[40] Thomas, f. o'boyle. 1989. «grappling with the expatriate issue --- little benefit to careers seen $\ln$ foreign stints». wall street journal, p. 1 .

[41] Torbiorn, i. (1982). living abroad. living abroad. new york, wiley

[42] Tung, r. 1982. «selecting and training procedures of u.s., european and japanese multinational corporations». california management review. vol. 25 , no 1 , p. 57-71.

[43] Tung, rosalie 1. 1981. «selection and training of personnel for overseas assignments». columbia journal ofworld business. vol. 16, no 1, p. 68.

[44] Tye, g. mary, et y. peter chen. 2005. «selection of expatriates: decision-making models used by $\mathrm{hr}$ professionals». hr. human resource planning. vol. 28, no 4,p. 15.

[45] Van der bank, m, et s rothmann. 2006. «correlates of expatriates cross-cultural adjustment ». management dynamics. vol. 15, no 4, p. 29.

[46] Van maanen, j, et e. e. lawler. 1972. «toward a theol"y of organisational socialization». research in organizational behaviour. vol. 1, p. 209-264.

[47] Viswesvaran, c, ll sanchez et j fisher. 1999. «the raie of social suppol1 in the process of work stress: a meta-analysis». journal of vocational behavior. vol. 54, p. 314-334.

[48] Wagner, n. 1998. les nouvelles elites de la mondialisation. paris: puf, $174 \mathrm{p}$.

[49] Waxin, marie-france, et jean-louis chandon. 2003. «l'adaptation au travail des expatries: ses antecedents et l'effet du pays d'origine». revue management international. vol. 47.
[50] Waxin, marie-france, et alexandra panaccio. 2005. «cross-cultural training to facilitate expatriate adjustment: it works!». personnel review. vol. 34, no 1, p. 51.

[51] Zhu, weichun, fred luthans, k. h chewirene et cuifang li. 2006. «potential expats in singaporean organizations». the journal of management development. vol. 25, no 8, p. 763. 